\title{
40. K-Ar AGES OF BASALT SILLS FROM DEEP SEA DRILLING PROJECT SITES 444 AND 446, SHIKOKU BASIN AND DAITO BASIN, PHILLIPINE SEA
}

\author{
Edwin H. McKee and Paul R. Klock, U.S. Geological Survey, Menlo Park, California
}

\section{INTRODUCTION}

Two core samples of basalt sills encountered on Leg 58 of the Deep Sea Drilling Project were dated by K-Ar, using conventional isotope-dilution methods (Dalrymple and Lanphere, 1969).

One sample (from Section 444A-1-2) is from a sill at Site 444 , on the east side of the Shikoku Basin. Sediment from a few meters beneath the sill was dated paleontologically at 14 to $15 \mathrm{~m} . \mathrm{y}$. (Klein and others, 1978); these authors estimated an age of 13 to 14 m.y. for the sill. This age is less than that predicted from the magnetic-anomaly age based on uniform spreading of a postulated extinct spreading center $95 \mathrm{~km}$ east of the drill site (Tomoda and others, 1975; Kobayashi and Isezaki, 1976). Because of the apparent youth of the sill, Klein and others (1978) postulated that it represents offridge volcanism in the Shikoku Basin.

The second sample (from Section 446A-11-2) is from a sill in the Daito Basin. Fossils in sediments above and below the sill indicate that it was emplaced during the late early Eocene or later.

\section{ANALYTICAL PROCEDURES AND RADIOMETRIC AGE}

Sample preparation and argon and potassium analyses were carried out in the U. S. Geological Survey laboratories at Menlo Park, California. The sample from Hole 444A was crushed, sieved to 60 to 100 mesh size, washed, and treated for 1 minute in 5 per cent $\mathrm{HF}$ and 30 minutes in 14 per cent $\mathrm{HNO}_{3}$ solutions, then loaded into a high-vacuum gas-extraction system. This treatment has proved advantageous in eliminating extraneous argon from whole-rock basalt samples. The sample from Hole 446A was crushed and washed, and hornblende in the size range of 80 to 100 mesh was separated by heavy-liquid methods. Potassium analyses of both samples were performed by a lithium metaborate flux fusion-flame photometry technique, the lithium serving as an internal standard (Ingamells, 1970). Argon analyses were performed by standard isotope-dilution procedures, using a $60^{\circ}$ sector, 15.2-cm-radius, Neirtype mass spectrometer, operated in the static mode for mass analyses.

The precision of the data, shown as the \pm value, is the estimated analytical uncertainty at one standard deviation. It represents uncertainty in the measurement of radiogenic ${ }^{40} \mathrm{Ar}$ and $\mathrm{K}$ in the sample and is based on experience with replicated analyses in the Menlo Park laboratories.
The decay constants used for ${ }^{40} \mathrm{~K}$ are

$$
\lambda_{e}+\lambda_{e}^{\prime}=0.581 \times 10^{-10} \mathrm{yr}^{-1}
$$

and

$$
\lambda_{\beta}=4.962 \times 10^{-10} \mathrm{yr}^{-1},
$$

and atomic abundance of ${ }^{40} \mathrm{~K}$ is taken to be $1.167 \times 10^{-4}$ mole/mole.

Analytical results and calculated radiometric ages are given in Table 1.

TABLE 1

Analytical Results and Ages

\begin{tabular}{lcccc}
\hline \multicolumn{5}{c}{ Parameters of Basalts } \\
\hline Hole & $\begin{array}{c}\mathrm{K}_{2} \mathrm{O} \\
(\mathrm{wt.} \%)\end{array}$ & $\begin{array}{c}\text { Radiogenic } \\
40 \mathrm{Ar} \\
(\mathrm{mole} / \mathrm{g})\end{array}$ & $\frac{\text { Radiogenic } 40_{\mathrm{Ar}}}{\text { Total } 40_{\mathrm{Ar}}}$ & $\begin{array}{c}\text { Age } \\
(\mathrm{m} . \mathrm{y} .)\end{array}$ \\
\hline $444 \mathrm{~A}$ & 1.38 & $2.932 \times 10^{-11}$ & 0.169 & $14.7 \pm 2.1$ \\
$446 \mathrm{~A}$ & 0.37 & $2.6015 \times 10^{-11}$ & 0.482 & $48.2 \pm 1.0$ \\
\hline
\end{tabular}

\section{INTERPRETATION}

The sample from Hole 444A, in the Shikoku Basin, which yielded a radiometric age of $14.7 \pm 2.1 \mathrm{~m}$.y., confirms the estimated age of the sill (Klein and others, 1978) and supports the thesis of post-spreading, offridge volcanism in this part of the basin.

The sample from Hole 446A, in the Daito Basin, which yielded a radiometric age of $48.2 \pm 1.0 \mathrm{~m} . \mathrm{y}$., dates from the late early Eocene to early middle Eocene, using the time scale of LaBrecque and others (1977). This age is consistent with the paleontological ages of sediments above and beneath the sill.

\section{REFERENCES}

Dalrymple, G. B., and Lanphere, M. A., 1969. Potassiumargon dating: San Francisco (W. H. Freeman).

Ingamells, C. O., 1970. Lithium metaborate flux in silicate analysis. Anal. Chim. Acta, 52(2), 323-334.

Klein, G. deV., Kobayashi, K., Chamley, H., Curtis, D. M., Dick, H. J. B., Echols, D. J., Fountain, D. M., Kinoshita, H., Marsh, N. G., Mizuno, A., Nisterenko, G. K., Okada, H., Sloan, J. R., Waples, D. M., and White, S. M., 1978. Off-ridge volcanism and seafloor spreading in the Shikoku Basin. Nature, 273, 746-748.

Kobayashi, K., and Isezaki, N., 1976. Magnetic anomalies in the Sea of Japan and the Shikoku Basin; possible tectonic implications. Am. Geophys. Union, Geophys. Monogr., 19, 235-251. 
LaBrecque, J. L., Kent, D. V., and Conde, S. C., 1977, Revised magnetic polarity time scale for Late Cretaceous and Cenozoic time. Geology, 5, 330-335.
Tomoda, Y., Kobayashi, K., Segawa, J., 1975. Linear magnetic anomalies in the Shikoku Basin, northeastern Philippine Sea. J. Geomagnet. Geoelec., 27 (1), 47-56. 